\title{
Androgen receptor as a regulator of ZEB2 expression and its implications in epithelial-to-mesenchymal transition in prostate cancer
}

\author{
Sheeba Jacob, S Nayak, Gwendolyn Fernandes', R S Barai ${ }^{2}$, S Menon ${ }^{3}$, U K Chaudhari, \\ S D Kholkute and Geetanjali Sachdeva
}

\author{
Primate Biology Laboratory, National Institute for Research in Reproductive Health (NIRRH), \\ Indian Council of Medical Research, JM Street, Parel, Mumbai 400012, India \\ ${ }^{1}$ GS Medical College and KEM Hospital, Parel, Mumbai 400012, India \\ ${ }^{2}$ The Centre for Medical Bioinformatics, NIRRH, Parel, Mumbai 400012, India \\ ${ }^{3}$ Department of Pathology, Tata Memorial Hospital, Mumbai 400012, India
}

Correspondence
should be addressed
to G Sachdeva
Email
sachdevag@nirrh.res.in

\begin{abstract}
Zinc finger E-box-binding protein 2 (ZEB2) is known to help mediate the epithelialto-mesenchymal transition, and thereby it facilitates cancer metastasis. This study was initiated to explore whether ZEB2 expression differs in prostate cancer $(\mathrm{PCa}, n=7)$ and benign prostatic hyperplasia (BPH, $n=7$ ) tissues. In PCa tissues, the levels of both immunoreactive ZEB2 and androgen receptor (AR) were found to be significantly higher $(P<0.05)$ when compared with BPH tissues. Co-regulation of AR and ZEB2 prompted us to investigate the role of androgenic stimuli in ZEB2 expression. ZEB2 expression was found to be significantly $(P<0.05)$ upregulated after androgen stimulation and downregulated following AR silencing in LNCaP cells, an androgen-dependent PCa cell line. This finding suggested $A R$ as a positive regulator of ZEB2 expression in androgen-dependent cells. Paradoxically, androgen-independent (AI) cell lines PC3 and DU145, known to possess low AR levels, showed significantly $(P<0.05)$ higher expression of ZEB2 compared with LNCaP cells. Furthermore, forced expression of AR in PC3 (PC3-AR) and DU145 (DU-AR) cells led to reductions in ZEB2 expression, invasiveness, and migration. These cells also exhibited an increase in the levels of E-cadherin (a transcriptional target of ZEB2). Co-transfection of $A R$ and $Z E B 2$ CDNA constructs prevented the decline in invasiveness and migration to a significant extent. Additionally, ZEB2 downregulation was associated with an increase in miR200a/miR200b levels in PC3-AR cells and with a decrease in miR200a/miR200b levels in AR-silenced LNCaP cells. Thus, AR acts as a positive regulator of ZEB2 expression in androgendependent cells and as a negative regulator in AI PCa cells.
\end{abstract}

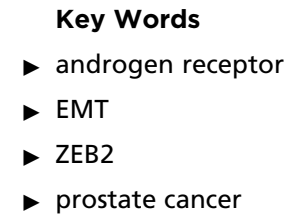

Endocrine-Related Cancer (2014) 21, 473-486

\section{Introduction}

It is well recognized that androgens play a vital role in development, growth, and progression of prostate cancer (PCa), the most common nondermatological malignancy in men (Mohler 2008). Surgical ablation of androgens and antiandrogen therapies are the major treatment modalities for locally advanced or metastatic PCa (Miyamoto et al. 2004). 
Although these treatment strategies are initially effective, the disease eventually progresses to an androgenindependent (AI) state (Feldman \& Feldman 2001). Nonetheless, AI PCa cells continue to rely on androgen receptor (AR) for their growth and survival (Balk 2002). Hence, AR-mediated signaling and its effectors are considered to be attractive targets for the treatment of $\mathrm{AI}$ PCa, which is often associated with metastasis.

Sufficient evidence has shown that the epithelialto-mesenchymal transition (EMT) facilitates metastasis of cancerous cells (Klymkowsky \& Savagner 2009). EMT is characterized by the gain of mesenchymal characteristics, such as mobility, invasiveness, and loss of epithelial features, that is, cell-cell adhesion, cell polarity, etc. Several strides have been carried out to identify the factors contributing to EMT in PCa. Transforming growth factor beta (Zhu \& Kyprianou 2010), nicotinamide adenine dinucleotide-dependent histone deacetylase or SIRT1 (Byles et al. 2012), platelet-derived growth factor (Kong et al. 2009), TMPRSS2/ERG (Leshem et al. 2011), SNAI2 (SLUG) (Emadi Baygi et al. 2010), DAB2IP (Xie et al. 2010), Hsp27 (HSPB1) (Shiota et al. 2013), and miRNAs (Ru et al. 2012) have all been identified as EMT regulators in PCa. Interestingly, the majority of these factors mediate EMT via zinc finger E-box-binding protein (ZEB) family members, such as ZEB1 ( $\delta E F 1$ or AREB6) and ZEB2 (Smad-interacting protein 1 (SIP1)) (Gregory et al. 2011).

The role of the androgen axis in PCa pathogenesis has been described previously (Nieto et al. 2007). However, data available on the role of androgens in EMT regulation are contradictory. While some investigators have reported androgen-induced activation of EMT and its effectors (Zhu \& Kyprianou 2010, Anose \& Sanders 2011), others have demonstrated EMT activation in response to androgen deprivation (Sun et al. 2012). A recent study by Izumi et al. (2013) has implicated AR as an inhibitor of EMT activation in PCa cells. These conflicting data warrant more studies directed toward deciphering the role of androgenic stimuli in EMT and PCa metastasis.

In this study, ZEB2 expression was examined in i) primary $\mathrm{PCa}$ and benign prostatic hyperplasia $(\mathrm{BPH})$ tissues, ii) an androgen-dependent (AR-positive) PCa cell line (LNCaP), before and after the attenuation of $\mathrm{AR}$ expression, and iii) AI PC3 and DU145 cells (expressing low levels of endogenous AR), before and after the forced expression of AR. We also investigated whether the modulation in ZEB2 expression is accompanied by any changes in downstream functions (e.g. invasion and migration).

\section{Materials and methods}

\section{Antibodies}

Human AR MABs and secondary antibodies conjugated to HRP or FITC were procured from Dako (Glostrup, Denmark). E-cadherin, p63, and glyceraldehyde-3-phosphate dehydrogenase (GAPDH) antibodies were purchased from BD Biosciences (San Jose, CA, USA), Sigma-Aldrich, and Calbiochem (Darmstadt, Germany) respectively. Human ZEB2 and $\alpha$-methylacyl-CoA racemase (AMACR) antibodies were purchased from Sigma-Aldrich, mouse and rabbit IgGs from Millipore (Billerica, MA, USA), Alexa Fluor 488-conjugated secondary antibodies from Life Technologies, and biotinylated secondary antibodies were from Vector Laboratories (Burlingame, CA, USA).

\section{Tissue samples}

Use of prostate tissue samples was approved by the NIRRH Ethics Committee for Clinical Studies. BPH tissues $(n=7)$ were obtained using transurethral resection and $\mathrm{PCa}$ biopsies $(n=7)$, by core needle biopsy.

\section{Immunohistochemistry}

Prostate tissue sections of $5 \mu \mathrm{m}$ thickness were deparaffinized and rehydrated in descending grades of methanol. After quenching endogenous peroxidase activity, sections were microwaved for $10 \mathrm{~min}$ in antigen unmasking solution (Vector Laboratories). For detection of nuclear proteins, sections were permeabilized in $0.1 \%$ Triton $\mathrm{X}-100$ in PBS (pH 7.4) for $10 \mathrm{~min}$. After blocking, sections were incubated with either the respective primary antibody or rabbit/mouse IgGs and then with biotinylated secondary antibodies. Reaction products were detected using avidin-biotin-HRP complex and diaminobenzidine. Immunostained sections were counterstained with hematoxylin.

Staining intensities of the immunoprecipitates were determined using an image analysis software Aperio Image Scope, version v11.2.0.780 (Aperio, Vista, CA, USA). A minimum of ten areas from each section were randomly selected for measuring integrated optical density.

\section{Cell lines and their maintenance}

Androgen-dependent prostate carcinoma LNCaP-FGC cell line (CRL-1740) was procured from the American

Published by Bioscientifica Ltd. 

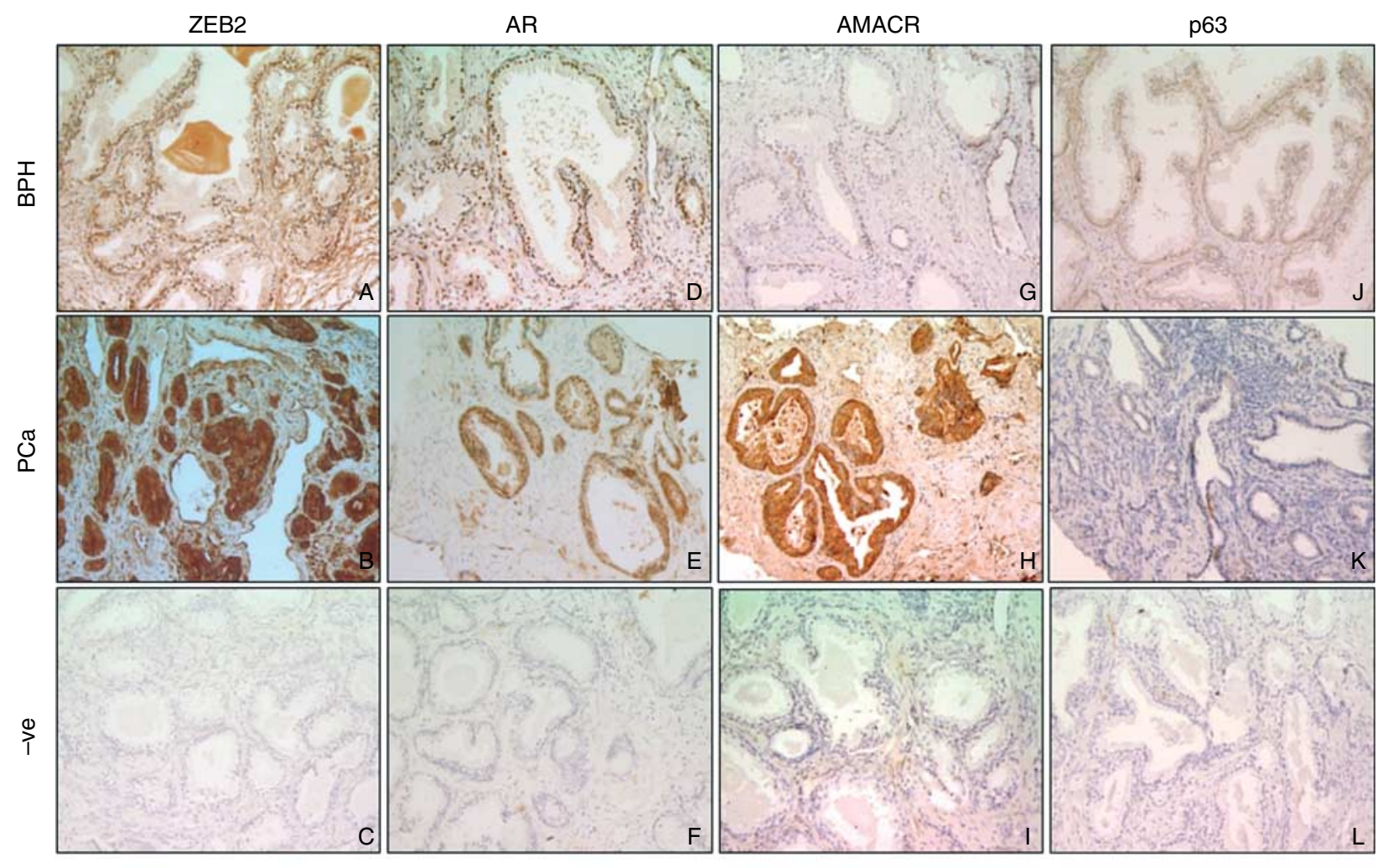

M

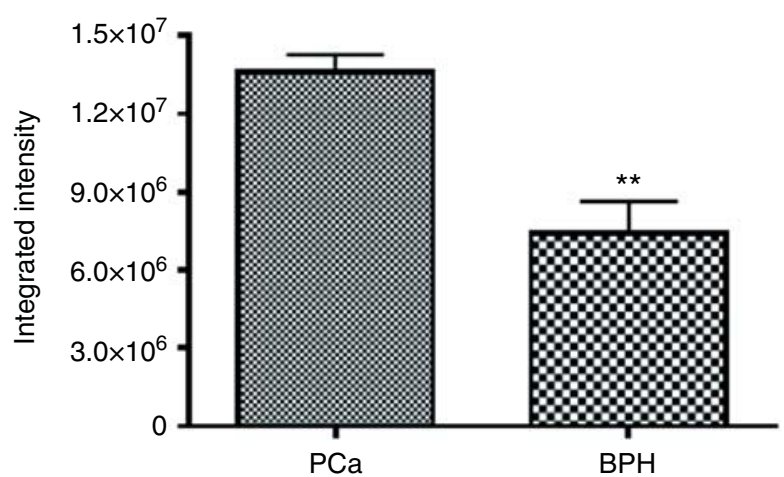

$\mathrm{N}$

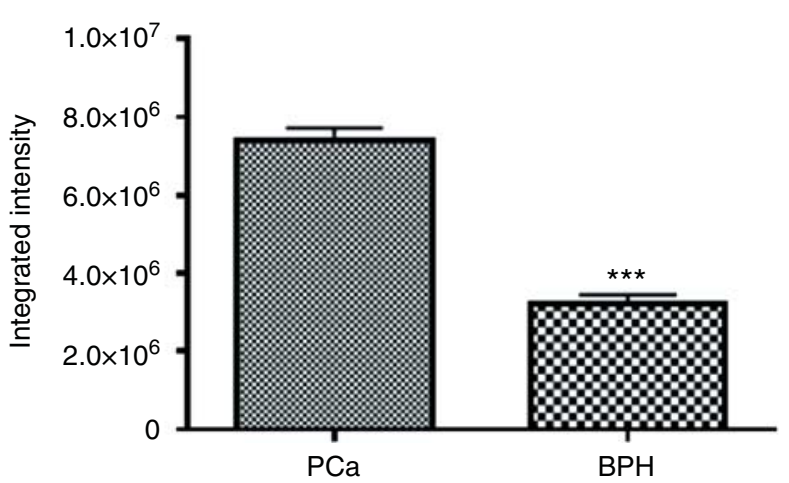

\section{Figure 1}

Immunolocalization of ZEB2 ( $A$ and $B$ ), AR ( $D$ and E), AMACR ( $G$ and $H$ ), and $p 63(\mathrm{~J}$ and $\mathrm{K}$ ) proteins to the prostate tissues of patients with benign prostatic hyperplasia (BPH) (A, D, G and J) and prostate cancer (PC) $(B, E, H$ and $K)$. (C, $F, I$ and $L)$ sections where primary antibodies were

Type Culture Collection (Manassas, VA, USA), whereas AI PCa cell lines, PC3 (CRL-1435) and DU145 (ATCCHTB-81), were obtained from National Centre for Cell Sciences (Pune, India). The cell lines were grown in phenol red-free RPMI-1640 media (Sigma-Aldrich), supplemented with 10\% fetal bovine serum (FBS), 100 units/ml penicillin, and $100 \mu \mathrm{g} / \mathrm{ml}$ streptomycin (Life Technologies, Invitrogen). Printed in Great Britain replaced with IgGs. Magnification $20 \times$. (M and N) semiquantitative analysis to compare the intensities of immunoreactive proteins ((M) ZEB2 and (N) AR) in BPH and PCa tissues. ** $P$ value $<0.001$ and $* * * P$ value $<0.0001$

\section{$5 \alpha$-Dihydrotestosterone stimulation experiments}

LNCaP cells $\left(1 \times 10^{5} /\right.$ well $)$, seeded in RPMI-1640 supplemented with $10 \%$ charcoal-stripped FBS, were stimulated with different concentrations of $5 \alpha$-dihydrotestosterone (DHT). After $72 \mathrm{~h}$, cell pellets were resuspended in protein lysis buffer (9 M urea, 4\% CHAPS (3-[(3'-cholamidopropyl)-dimethylammonio]-1-propanesulfonate), and $40 \mathrm{mM}$ Tris) to obtain total protein extracts.

Published by Bioscientifica Ltd. 

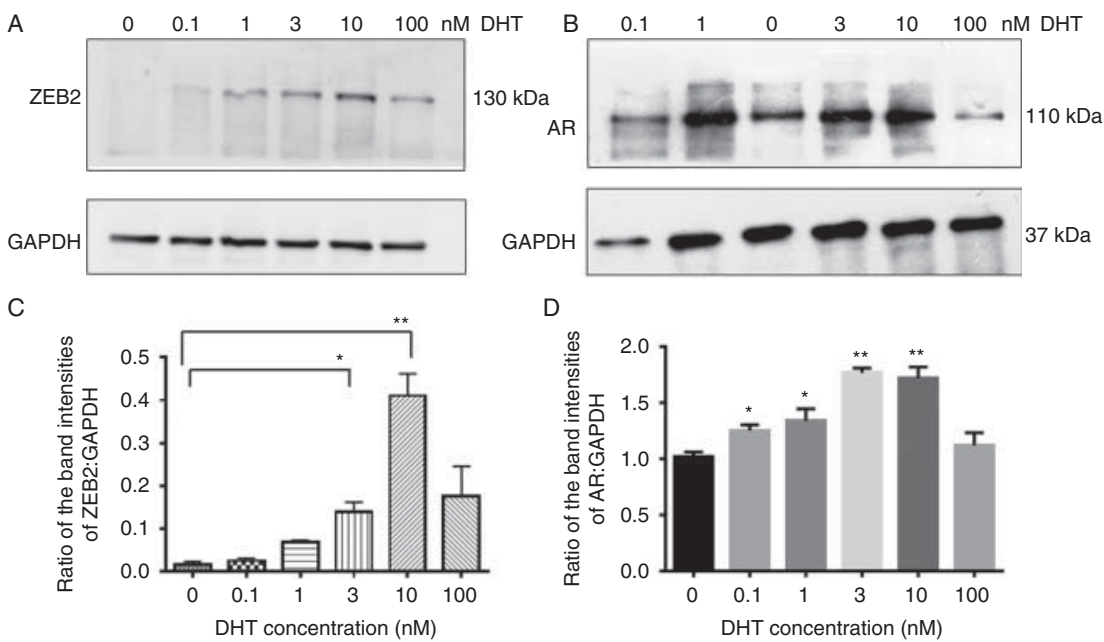

D

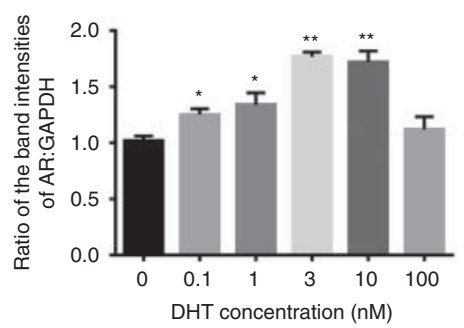

Figure 2

Detection of ZEB2 (A) and AR (B) proteins in androgen-stimulated LNCaP cells. Blots were reprobed to detect GAPDH for normalization of total protein load. (C and D) Densitometric analyses to depict the ratios of

the intensities of ZEB2 or AR:GAPDH respectively. ${ }^{\star} P$ value $<0.05$ and $* * P$ value $<0.005$

Relative quantity $\left(\mathrm{RQ}=2^{\Delta \Delta C t}\right)$ of transcripts was calculated by the $\Delta \Delta C t$ method, in which expression of the target gene is normalized against $18 \mathrm{~S}$ rRNA expression. $\Delta C t$ was calculated by subtracting $C t$ of the endogenous control from that of the target gene and $\Delta \Delta C \mathrm{t}$ was calculated by subtracting $\Delta C \mathrm{t}$ of control from that of test. The values were expressed as $\mathrm{RQ} \pm$ s.E.M.

\section{miRNA isolation}

miRNAs were extracted using the mirVana miRNA isolation kit (Life Technologies) according to the manufacturer's instructions. RNA samples were converted to cDNA using miRNA gene-specific primers and a TaqMan miRNA RT Kit (ABi). TaqMan primer/probes (Life Technologies) were used for amplification of the MIR200A and MIR200B genes. A conserved region of U6 (RNU6-50P) snRNA was amplified in each sample to normalize the RNA input among different samples.

\section{Immunoblotting}

Nuclear proteins were extracted using a ProteoJET cytoplasmic and nuclear protein extraction kit (Thermo Fisher Scientific, Waltham, MA, USA) as per the manufacturer's instructions. Extracts of total protein were obtained by suspending cells in protein lysis buffer. Nuclear or total proteins $(10 \mu \mathrm{g})$, resolved in 10\% SDS-PAGE gels, were transferred to PVDF membranes (Millipore). After blocking,

Published by Bioscientifica Ltd http://erc.endocrinology-journals.org DOI: 10.1530/ERC-13-0514
(C) 2014 Society for Endocrinology Printed in Great Britain 

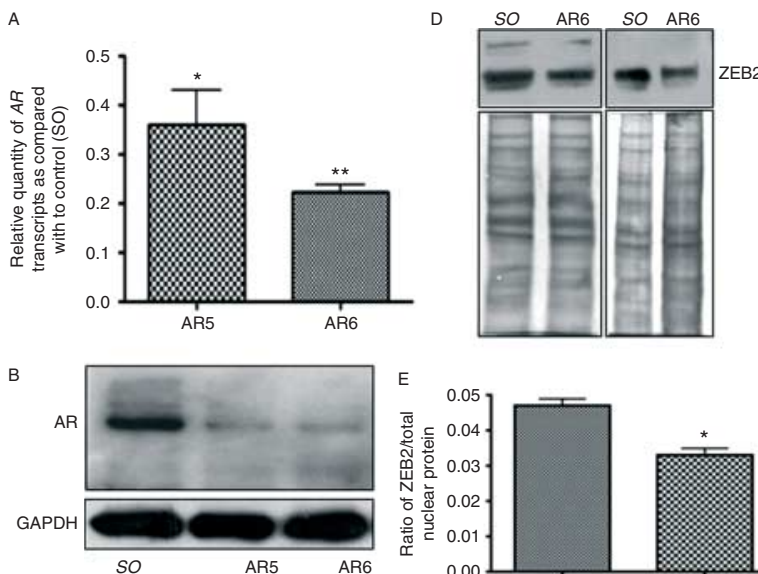

so

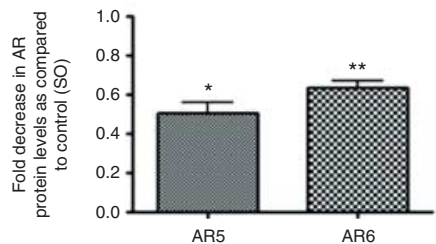

$\mathrm{F}$
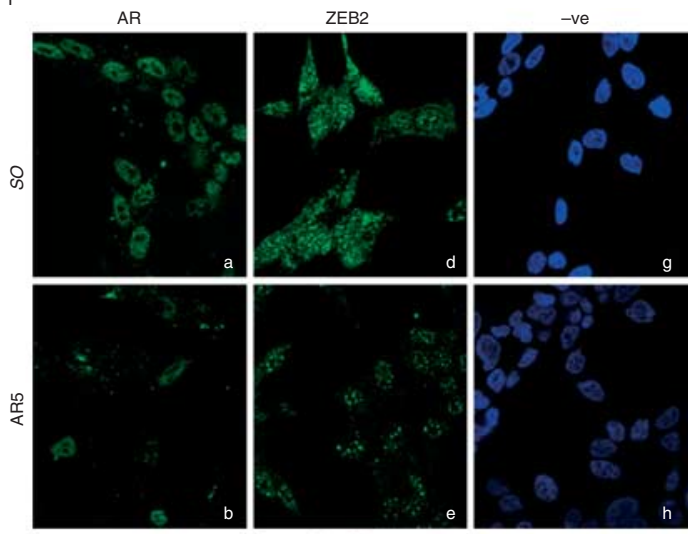

\section{Figure 3}

Relative levels of $A R$ transcript (A) and AR protein (B) in LNCaP cells transfected with AR5/AR6 siRNAs, compared with those transfected with scrambled siRNA (SO). (C) Fold change obtained by densitometric analysis of the ratios of the intensities of AR to that of GAPDH in AR- and SO-transfected cells. (D) ZEB2 protein levels in the nuclear extracts of $A R$ - and SO-transfected cells. The blot was stained with Coomassie blue after immunodetection, to normalize

the blots were sequentially incubated with the respective primary and secondary antibodies. Immunoreactive bands were detected using an Advanced ECL detection kit (Amersham) and their densities were measured using the IQTL Software (GE Biosciences, Pittsburgh, PA, USA).

\section{Immunofluorescence and phalloidin staining}

Cells, fixed in $3.7 \%$ paraformaldehyde in PBS, were permeabilized in $0.1 \%$ Triton X-100. Blocking (1\% BSA for $1 \mathrm{~h}$ ) was followed by incubation with appropriate primary antibodies and then with FITC or Alexa Fluor-conjugated secondary antibody. For F-actin staining, fixed and permeabilized cells were incubated with Phalloidin stain (Life Technologies) for 30 min and analyzed using confocal laser microscopy (Carl Zeiss, Jenna, Germany).

\section{In vitro invasion assay}

Cells $\left(2 \times 10^{5}\right)$ suspended in $250 \mu$ l plain media were placed in the top chamber of matrigel-coated transwells (Nunc, Roskilde, Denmark). Transwells without matrigel were nuclear protein load. (E) Densitometric analysis to depict the ratios of ZEB2:total nuclear protein load. * $P$ value $<0.05$ and $* * P$ value $<0.005$. (F) Immunofluorescent detection of AR ( $a, b$ and c) and ZEB2 (d, e and f) proteins in LNCaP cells, transfected with either SO siRNA ( $a$ and d) or AR siRNAs (AR5 ( $b$ and $e$ ) and AR6 ( $c$ and $f$ )). In negative controls ( $g$ and $h$ ), primary antibodies were replaced with mouse or rabbit IgGs. Magnification, $63 \times$.

used as controls. Medium with $10 \%$ sera was added to the lower chamber. After $48 \mathrm{~h}$, transwells were permeabilized and hematoxylin stained. Non-invading cells were removed from the top of transwells. The percentage of invasion was calculated using the following formula. Number of cells in the control transwell-number of cells in the transwell containing matrigel/100.

\section{Wound-healing assays}

Cells $\left(5 \times 10^{5}\right)$ were treated with $5 \mu \mathrm{g} / \mathrm{ml}$ Mitomycin C (Sigma-Aldrich) for $2 \mathrm{~h}$. This was followed by creation of a wound using a sterile $200 \mu \mathrm{l}$ micropipette tip. Images of different regions of the wound at 0 and $24 \mathrm{~h}$ were taken. The percentage of the wound covered was calculated using the following formula: distance of the wound after $24 \mathrm{~h} /$ distance of the wound at $0 \mathrm{~h} \times 100$.

\section{Statistical analysis}

Data are expressed as mean \pm s.D. Student's unpaired $t$-test was used to determine the significance of difference

Published by Bioscientifica Ltd. 

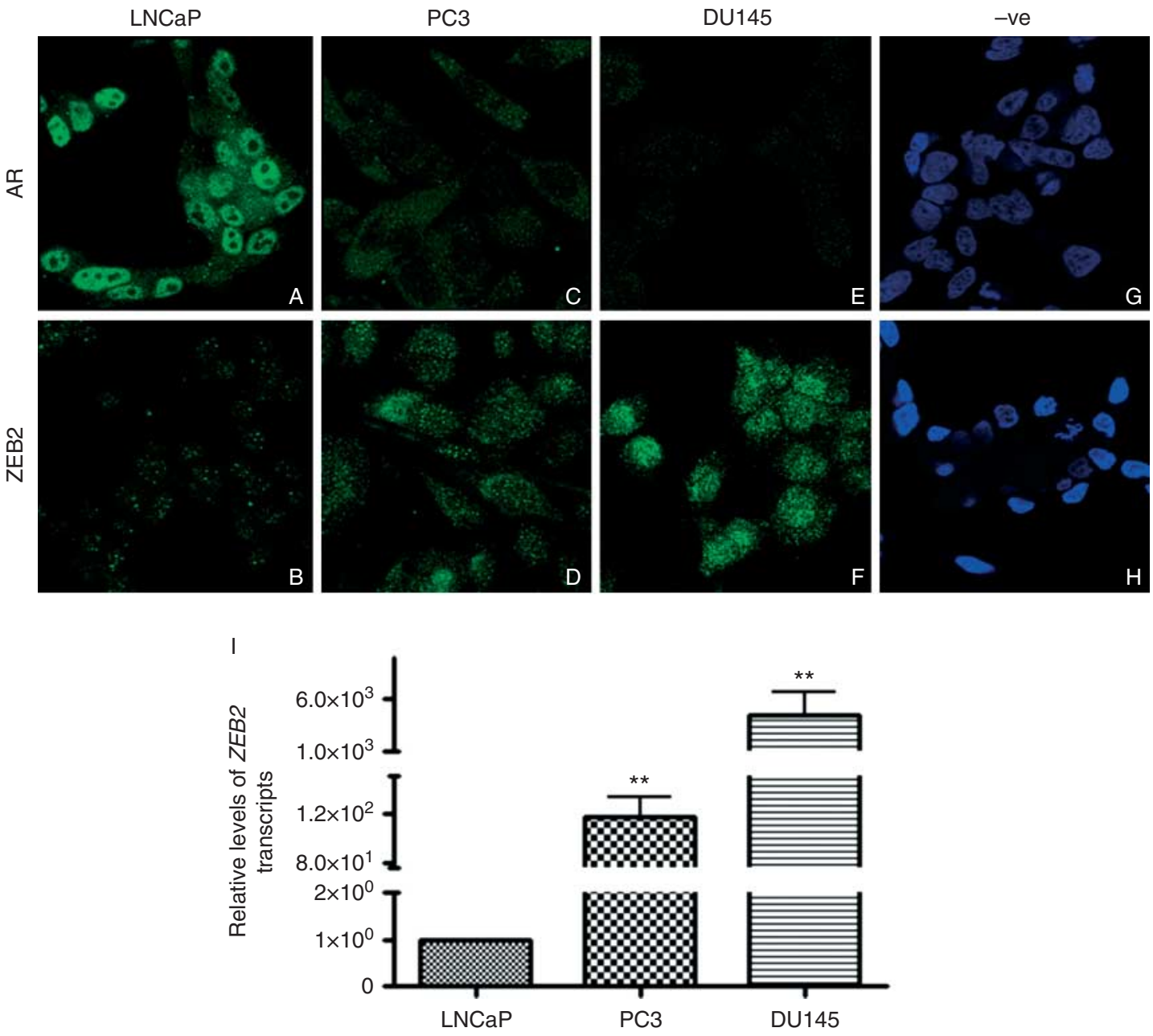

Figure 4

Immunofluorescent detection of AR (, , C and E) and ZEB2 (B, D and F) proteins in androgen-dependent $\mathrm{LNCaP}$ ( $\mathrm{A}$ and $\mathrm{B})$, and androgenindependent PC3 (C and D) and DU145 (E and F) cells. In negative controls,

between control and experimental samples. A $P$ value of $<0.05$ was considered to be significant.

\section{Results}

\section{Immunoreactive ZEB2 and AR levels are elevated in PCa tissues}

$\mathrm{BPH}$ and primary $\mathrm{PCa}$ tissues were immunostained for AMACR (Fig. 1G and H) and p63 (TP63) (Fig. 1J and K), to distinguish the glands representing $\mathrm{PCa}$ and $\mathrm{BPH}$ phenotypes respectively.

In BPH tissues, AR was immunolocalized to the nuclei of the secretory epithelial cells. AR immunostaining was weak or negligible in the basal epithelial cells of $\mathrm{BPH}$ primary antibodies were replaced with mouse lgGs (G) or rabbit lgGs $(H)$. Magnification $63 \times$. (I) Relative levels of ZEB2 transcripts in PC3 and DU145 cells, compared with LNCaP cells. ${ }^{*} P$ value $<0.005$.

tissues (Fig. 1D and Supplementary Fig. 2, see section on supplementary data given at the end of this article). On the other hand, immunoreactive AR was predominantly localized to the cytoplasm of the secretory epithelial cells in PCa tissues.

ZEB2 protein was detected in the nuclei of the secretory and basal epithelial cells in the BPH tissues (Fig. 1A and Supplementary Fig. 2). In PCa tissues, it was localized to nuclear as well as cytoplasmic compartments of the secretory epithelial cells (Fig. 1B and Supplementary Fig. 2). Semiquantitative analyses indicated significantly higher expression of ZEB2 $(P<0.001)$ and AR proteins $(P<0.0001)$ in the secretory epithelial cells of $\mathrm{PCa}$, compared with BPH tissues (Fig. $1 \mathrm{M}$ and N). 

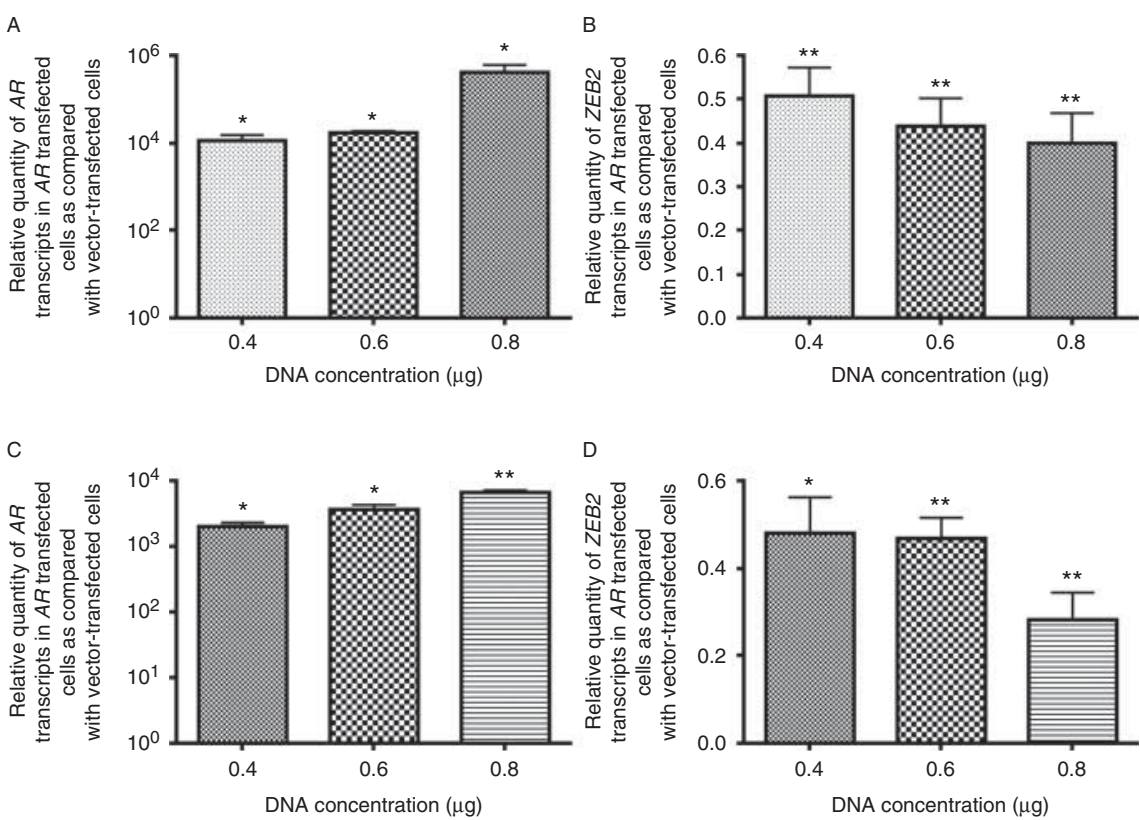

Figure 5

Relative levels of $A R$ ( $A$ and $C$ ) and ZEB2 (B and D) transcripts in AR overexpressing PC3 ( $A$ and B) or DU145 (C and D) cells, compared with the respective empty vector-transfected parental cells. ${ }^{*} P$ value $<0.05$ and $* * P$ value $<0.005$

\section{ZEB2 expression is stimulated by androgen in LNCaP cells}

DHT stimulation led to a dose-dependent (0.1-10 nM) increase in the levels of ZEB2 (Fig. 2A and C) and AR (Fig. 2B and D) in androgen-dependent LNCaP cells. Interestingly, both AR and ZEB2 levels were found to be lesser in $100 \mathrm{nM}$ treated cells, compared with $10 \mathrm{nM}$ treated cells. Thus, ZEB2 and AR proteins appeared to be co-regulated in response to androgen stimulation. Results suggested a positive regulation of ZEB2 expression by androgens in androgen-dependent cells.

\section{ZEB2 expression is regulated by AR in LNCaP cells}

LNCaP cells were transfected with different concentrations of AR5 and AR6 siRNAs (data not shown). Maximal inhibition of AR expression was observed in cells transfected with $15 \mathrm{nM}$ siRNAs (AR5 and AR6). The levels of $A R$ transcript (Fig. 3A) and AR protein (Fig. 3B and C) were significantly lesser $(P<0.05)$ in the $A R$-silenced cells, compared with the $S O$-transfected cells.

The levels of nuclear ZEB2 were found to be significantly $(P<0.05)$ lesser in the $A R$-silenced cells, compared with the $S O$-transfected cells (Fig. 3D and E). The decrease in nuclear ZEB2 levels hinted at the possibility of a decline in the transcriptional activity of ZEB2.
Immunocytochemical localization corroborated the results obtained by q-PCR and immunoblotting. As expected, immunoreactive $\mathrm{AR}$ levels were lesser in $A R$ siRNA-transfected cells (Fig. 3Fb and c), compared with SO-transfected cells (Fig. 3Fa). Immunoreactive ZEB2 protein levels were also found to be lower, especially in the nuclei of $A R$-silenced cells (Fig. 3Fe and $\mathrm{f}$ ). This reaffirmed that $\mathrm{AR}$ is a positive regulator of ZEB2 expression in androgen-dependent LNCaP cells.

\section{Basal levels of AR and ZEB2 in androgen-dependent and Al cells}

Immunoreactive AR levels were higher in androgendependent LNCaP cells (Fig. 4A), than in AI PC3 and DU145 cells (Fig. 4C and E). By contrast, basal levels of ZEB2 protein as well as transcripts were found to be higher in PC3 and DU145, than in LNCaP cells (Fig. 4A, B, C, D, E, F, G, H and I). Thus, ZEB2 expression appeared to be correlated with metastasis. It is well established that PC3 and DU145 cells are more aggressive, compared with LNCaP cells. This was further corroborated by higher expression of vimentin (i.e. mesenchymal marker) and lesser expression of E-cadherin (i.e. epithelial marker) in PC3 and DU145 cells, compared with LNCaP cells

Published by Bioscientifica Ltd. 

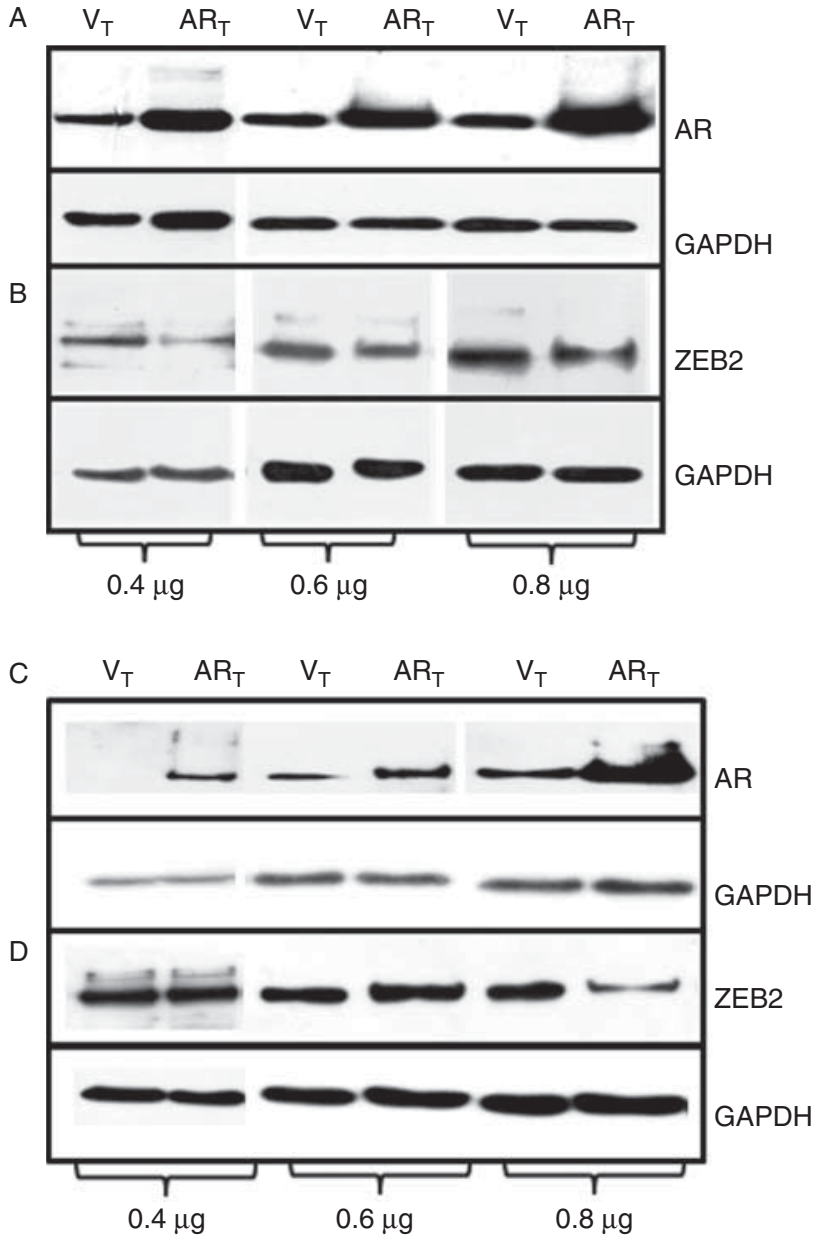

Figure 6

AR ( $A$ and $C$ ) and ZEB2 ( $B$ and $D$ ) protein levels in AR overexpressing PC3 ( $A, B$ and $E$ ) and DU145 ( $C, D$ and $F$ ) cells $\left(A R_{T}\right)$, and the respective empty vector-transfected parental cells $\left(V_{T}\right)$. Blots were reprobed for GAPDH to

(Supplementary Fig. 3, see section on supplementary data given at the end of this article).

\section{AR as a regulator of ZEB2 expression in PC3 and DU145 cells}

Then, we investigated whether an increase in the levels of AR modulates the ZEB2 expression in AI cells. Transfection of PC3 (Figs 5A and 6A) and DU145 cells (Figs 5C and 6C) with the $A R$ cDNA construct led to a significant $(P<0.05)$ increase in the levels of $A R$ transcript (Fig. $5 \mathrm{~A}$ and $\mathrm{C}$ ) and also in the levels of AR protein (Fig. 6A and C). However, ZEB2 was found to be significantly $(P<0.05)$ downregulated at the transcript (Fig. $5 \mathrm{~B}$ and $\mathrm{D}$ ) and protein levels (Fig. 6B and D) in $A R$-transfected cells. Extent of the decrease in ZEB2 levels was proportional to the increase in
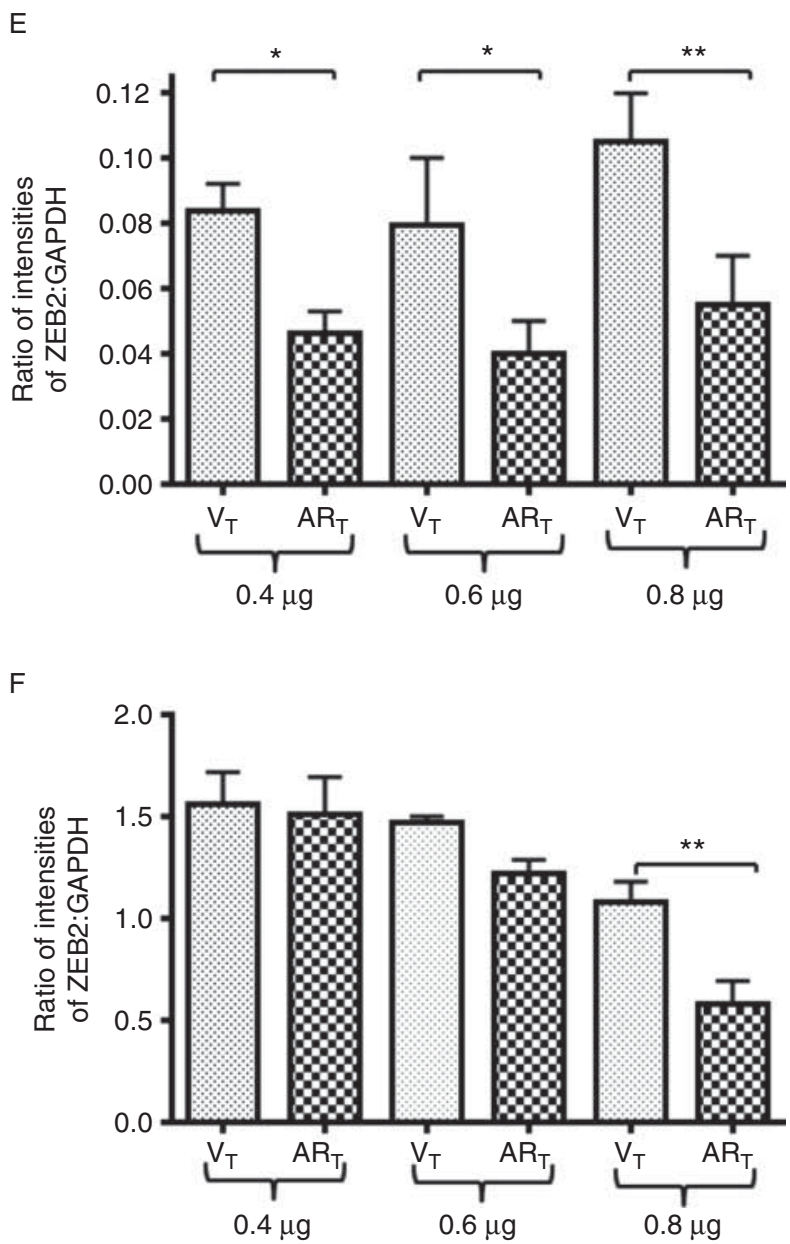

normalize the total protein load. ( $E$ and $F$ ) Densitometric analyses to depict the ratios of the intensities of ZEB2 to that of GAPDH in $V_{T}$ and $A R_{T}$ cells. $* P$ value $<0.05$ and $* * P$ value $<0.005$

AR levels (Fig. 6E and F). Thus, in AI cells, AR acts as a negative regulator of ZEB2 expression.

\section{E-cadherin expression is upregulated in AR overexpressing PC3/DU145 cells}

Immunofluorescent localization and immunoblotting revealed higher levels of E-cadherin in AR overexpressing PC3 cells (PC3-AR), compared with the parental PC3 cells (Fig. 7Aa, e and B). This pattern was also evident in DU-AR cells (Fig. 7Ac, $g$ and C). It is likely that the decline in ZEB2 levels contributes to higher expression of E-cadherin in PC3-AR and DU-AR cells.

PC3-AR and DU145-AR cells, displaying modulation in the levels of ZEB2 and E-cadherin, appeared to be morphologically distinct (Fig. 7Af and $\mathrm{h}$ ) from their respective

Published by Bioscientifica Ltd. 
A
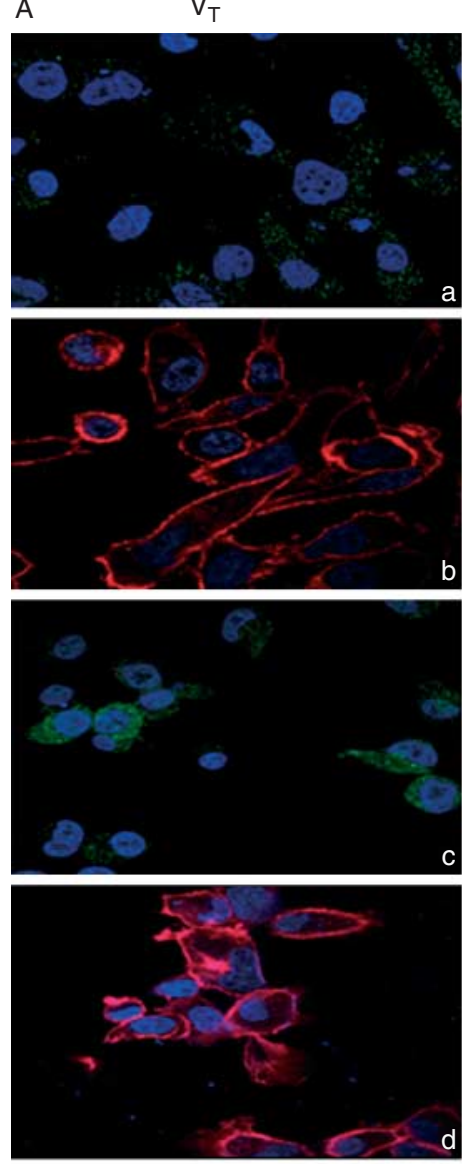
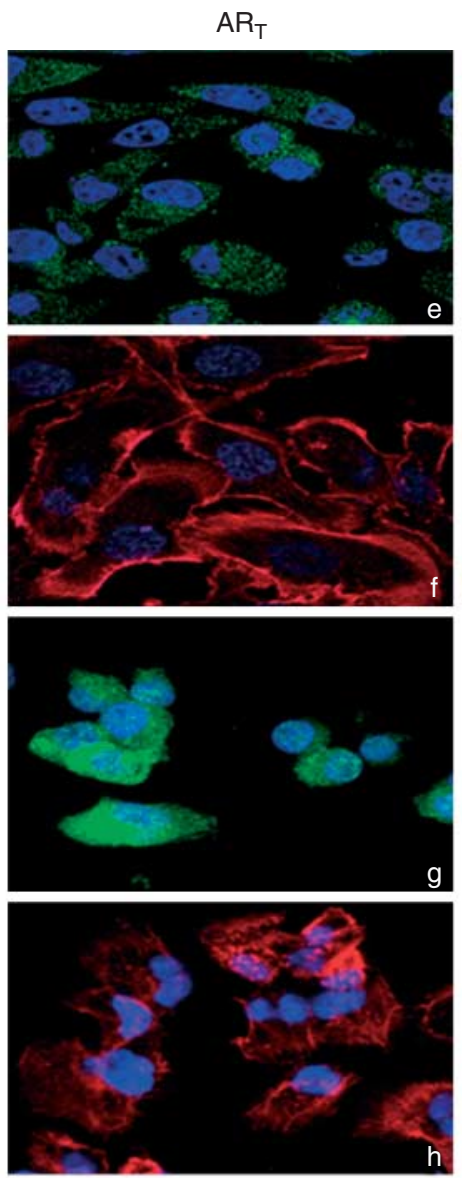
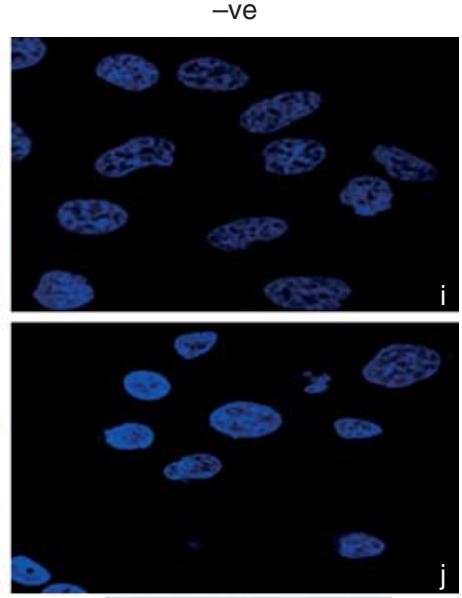

B

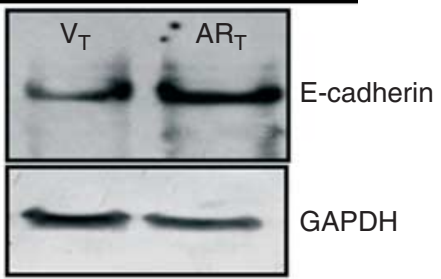

C

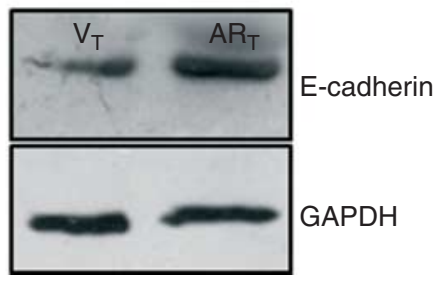

Figure 7

(A) Detection of E-cadherin by immunofluorescence (a, e, c and g) and detection of F-actin by phalloidin staining $(b, f, d$ and $h)$ in PC3 $(a, b$, e and f) and DU145 (c, d, g and h) cells, transfected with either the empty vector

parental cells (Fig. 7Ab and d). They looked more epithelioid and had more intense and diffused F-actin localization, as indicated by phalloidin staining (Fig. $7 \mathrm{f}$ and $\mathrm{h}$ ).

\section{A decrease in ZEB2 expression is associated with reduced invasiveness and migration in AR overexpressing PC3/DU145 cells}

AR overexpression led to a significant $(P<0.05)$ reduction in the invasiveness (Fig. 8B and D) and migration (Fig. 9) of PC3 and DU145 cells. To validate the assumption that ARinduced reduction in ZEB2 levels contributes to a decrease in invasion and migration, PC3 and DU145 cells were co-transfected with the cDNA constructs encoding AR and ZEB2 proteins (Figs 8 and 9). An increase in the levels of ZEB2 restored invasion (Fig. 8B and D) and migration (Fig. 9), to a significant $(P<0.05)$ extent, in the co-transfected cells.
$\left(V_{T}\right)(a, b, c$ and $d)$ or $A R$ cDNA constructs $\left(A R_{T}\right)(e, f, g$ and $h)$. ( $i$ and $\left.j\right)$ Mouse IgGs stained PC3 and DU145 cells respectively. (B) (PC3) and (C) (DU145)

Immunodetection of E-cadherin in the protein lysates of $V_{T}$ and $A R_{T}$ cells.

\section{miR200a and miR200b levels are altered in PC3-AR cells}

miR200a and miR200b levels were found to be significantly $(P<0.005)$ higher in LNCaP, compared with PC3 and DU145 cells (Fig. 10A). A similar pattern was observed for the AR protein in these cell lines (Fig. 4A, B, C, D, E, F, G and $\mathrm{H}$ ). On the other hand, ZEB2 protein demonstrated a reverse pattern, i.e. highest levels in DU145 and lowest levels in LNCaP cells (Fig. 4A, B, C, D, E, F, G and H). This prompted us to in silico explore the presence of androgen response elements (AREs) and ZEB2-binding sites in MIR200A and MIR200B genes.

Using an in-house Perl-based tool, regions spanning 1-1000 bp upstream of the transcription initiation sites in MIR2OOA and MIR2OOB genes were scanned for the presence of ZEB2-binding sites - CACCTG (E-BOX2), CAGGTG (Z-BOX1), and CAGGTA (Z-BOX2). MIR200A

Published by Bioscientifica Ltd. 
A

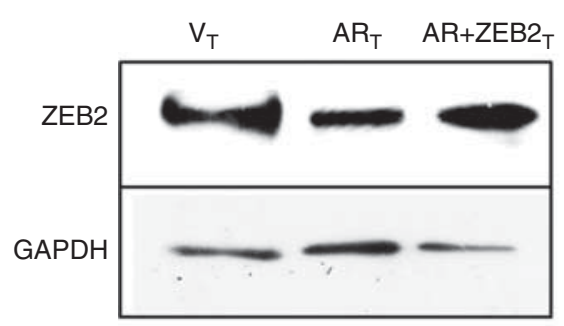

B

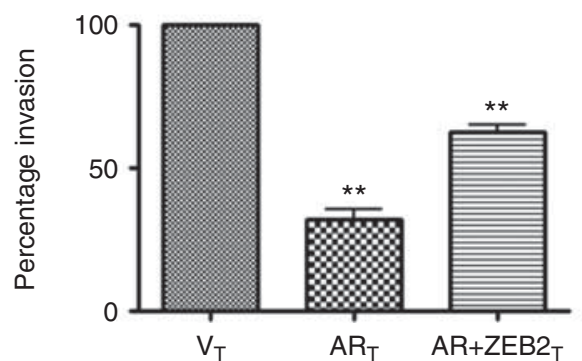

C

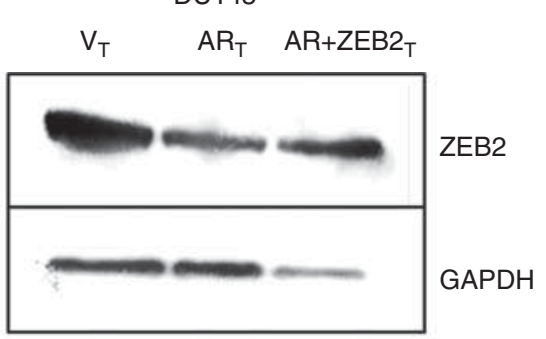

D

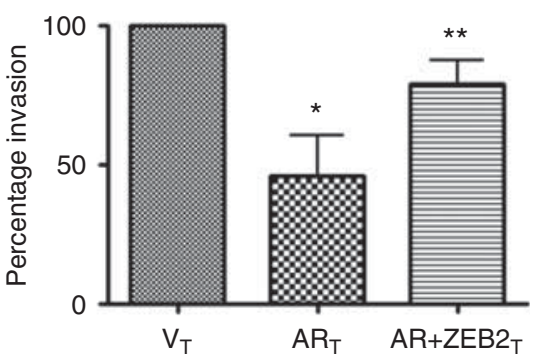

Figure 8

ZEB2 levels in the protein lysates of PC3 (A) and DU145 (C) cells transfected with either empty vector $\left(\mathrm{V}_{\mathrm{T}}\right)$ or $A R\left(A R_{\mathrm{T}}\right)$ or $A R+Z E B 2\left(\mathrm{AR}+\mathrm{ZEB} 2_{\mathrm{T}}\right)$. Percentage of invasion in PC3 (B) and DU145 (D) cells of $\mathrm{V}_{\mathrm{T},} A \mathrm{R}_{\mathrm{T}}$ and $\mathrm{AR}+\mathrm{ZEB} 2_{\mathrm{T}}$ cells. ${ }^{*} P$ value $<0.05$ and $* * P$ value $<0.005$.

and MIR200B genes were found to have ZEB2-binding sites (Table 1). AREs were not present in the scanned regions.

$A R$ silencing in LNCaP cells led to a significant decrease in miR200a and miR200b levels (Supplementary
Fig. 4, see section on supplementary data given at the end of this article). This indicated the possibility of AR being a positive regulator of MIR200A/MIR200B expression in androgen-dependent LNCaP cells. In AI PC3 cells also, an
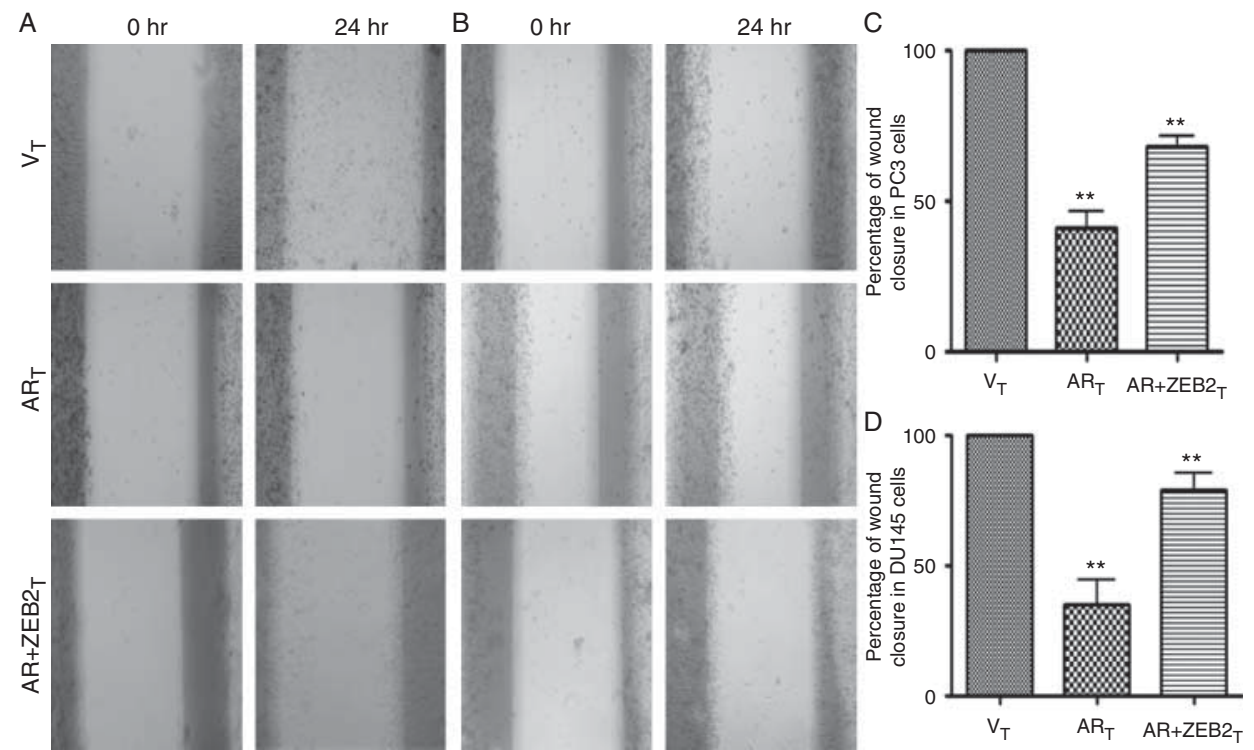

\section{Figure 9}

Wound healing in PC3 ( $A$ and $C$ ) and DU145 (B and $D)$ cells transfected with either the empty vector $\left(\mathrm{V}_{\mathrm{T}}\right)$, or $A R\left(A R_{\mathrm{T}}\right)$ or $A R+Z E B 2$ constructs (AR $\left.+Z E B 2 \mathrm{~T}\right)$. Magnification, $4 \times$. (C and D) The percentage of wound closures. ${ }^{*} P$ value $<0.005$.

http://erc.endocrinology-journals.org DOI: 10.1530/ERC-13-0514
(C) 2014 Society for Endocrinology Printed in Great Britain
Published by Bioscientifica Ltd. 
A

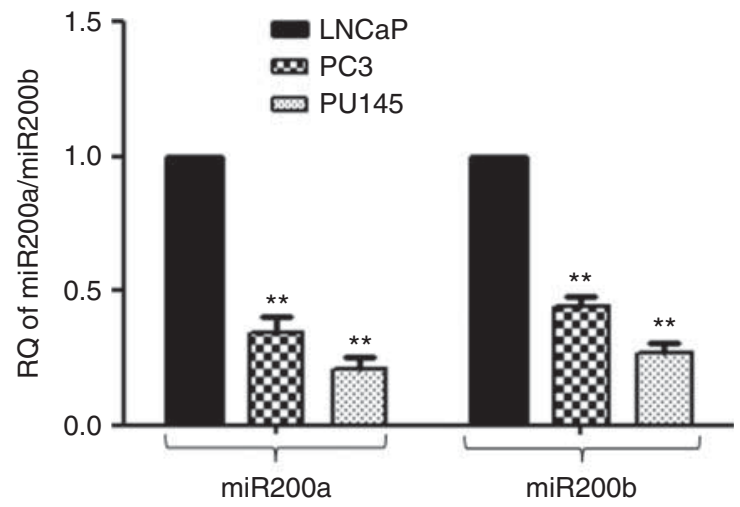

B

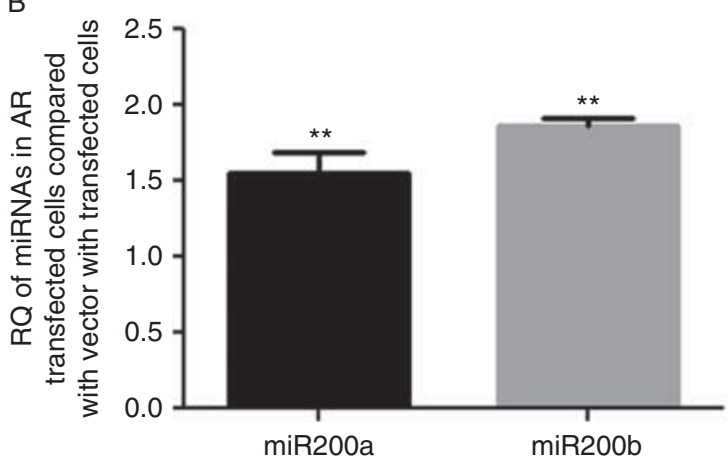

\section{Figure 10}

(A) miR200a and miR200b levels in androgen-independent PC3 and DU145 cells, compared with androgen-dependent LNCaP cells. (B) miR200a and miR200b levels in AR overexpressing PC3 cells. ${ }^{*} P$ value $<0.05$ and $* * P$ value $<0.005$.

increase was observed in the miR200a/miR200b levels, after AR overexpression (Fig. 10B). The increase in miR200a/miR200b levels could be either a cause or a result of the decrease in ZEB2 levels in PC3-AR cells.

\section{Discussion}

EMT is a major event that enables tumor cells to become metastatic (Thiery \& Sleeman 2006). Cells undergoing EMT demonstrate a decrease in the expression levels of epithelial proteins such as E-cadherin and junction plakoglobin, and an increase in the expression of mesenchymal markers, such as vimentin, fibronectin, and $\alpha$-smooth muscle actin (Acloque et al. 2009). These alterations lead to the loss of cell-cell adhesion and a gain of mobility. EMT is also known to be associated with the expression of ZEB2 during development (Vandewalle et al. 2005). ZEB2 expression has also been reported in tumors of the breast, stomach, liver, and ovary (Katoh \& Katoh 2009). This study showed significantly higher levels of immunoreactive ZEB2 in PCa compared with BPH tissues. PCa tissues also showed significantly higher levels of AR. These findings raise the possibility of the co-regulation of AR and ZEB2 and also the existence of a functional nexus between these two transcription factors.

Our data demonstrate the positive regulation of ZEB2 expression by androgens in androgen-dependent LNCaP cells. The entry of the mouse Zeb2 gene into the database of androgen-responsive genes (http://argdb.fudan.edu.cn/) is in agreement with our observations. Our microarray data also demonstrate a twofold decrease in the levels of ZEB2 transcripts, following the silencing of AR expression in LNCaP cells (data not shown). By contrast, an inverse relationship was observed between AR and ZEB2 in AI PC3 and DU145 cells, known for their low levels of AR expression (Alimirah et al. 2006). These cells, when overexpressing $\mathrm{AR}$, show a significant decline in ZEB2 levels. This in turn leads to a reduction in the invasiveness and migration of PC3-AR/DU-AR cells, which could have occurred due to a modulation in the levels of E-cadherin, a transcriptional target of ZEB2 (Postigo \& Dean 2000). Indeed, an increase in the levels of E-cadherin was observed in PC3-AR and DU145-AR cells. Co-transfection with a ZEB2 cDNA construct prevented the decline in invasiveness and migration. An increase in E-cadherin expression and a decline in invasiveness and migration were probably downstream effects of reduced levels/ activity of ZEB2 in AR overexpressing AI cells.

Attempts were also made to investigate whether the AR-mediated modulation in ZEB2 levels involves posttranscriptional regulation by miRNAs. There is evidence to suggest that miR200 family members regulate EMT by targeting ZEB proteins (Gregory et al. 2008). This finding encouraged us to investigate the possibility of a relationship between miR200a/miR200b and AR. Basal levels of $\mathrm{miR} 200 \mathrm{a} / \mathrm{miR} 200 \mathrm{~b}$ were found to be significantly higher

Table 1 In silico scanning for the presence of ZEB2-binding sites in the regulatory regions ( -1 to $-1000 \mathrm{bp})$ of MIR200A and MIR200B genes

\begin{tabular}{llc}
\hline Gene names & & Accession number \\
& & $\mathrm{Gi}: 224589800$ \\
$M I R 200 B$ & $\mathrm{Gi}: 224589800$
\end{tabular}

\begin{tabular}{|c|}
\hline Regions scanned \\
\hline $\begin{array}{llll}1 & 102 & 243-1 & 103 \\
1 & 242 \\
1 & 101 & 484-1 & 102483\end{array}$ \\
\hline
\end{tabular}

\begin{tabular}{c} 
E-box2 CACCTG \\
- \\
- \\
\hline
\end{tabular}

\begin{tabular}{c} 
Z-box1 CAGGTG \\
\hline$-941,-418,-364$ \\
$-938,-494,-182$
\end{tabular}

Z-box2 CAGGTA $-938,-494,-182$ 
Androgen-dependent cells

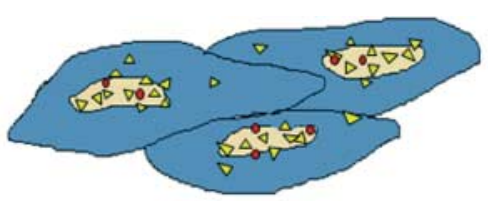

Higher levels/activity of $A R$

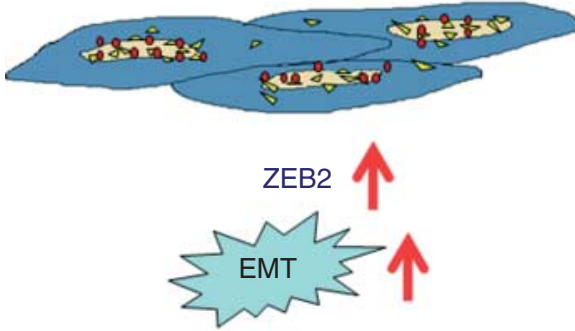

Androgen-independent cells
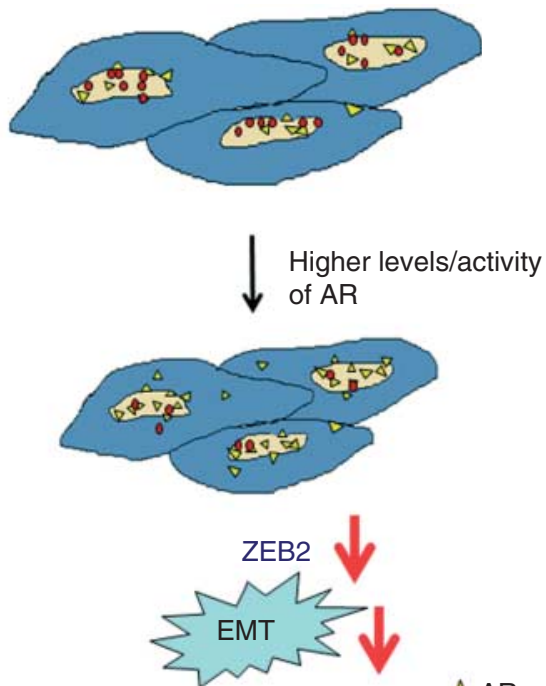

\section{$\triangle A R$}

Figure 11

EMT regulation by androgen receptor (AR) in prostate cancer is a cell context-dependent phenomenon. AR acts as a positive regulator of ZEB2 expression and EMT in androgen-dependent cells and as a negative regulator in androgen-independent prostate cancer cells.

in LNCaP cells compared with PC3 and DU145 cells. This observation partly explains the lower abundance of ZEB2 in LNCaP cells. Furthermore, $A R$ silencing in LNCaP cells led to a decrease in the levels of miR200a/miR200b. This finding lends credence to the possibility that $A R$ is a positive regulator of miR200 expression in androgendependent LNCaP cells (Supplementary Fig. 3). However, the $A R$ silencing-mediated decrease in miR200a/miR200b levels was not accompanied by an increase in ZEB2 expression in LNCaP cells. It is likely that the AR-mediated upregulation of ZEB2 expression in LNCaP cells does not rely on the participation of miR200a/miR200b.

In AI PC3 cells, AR overexpression leads to an increase in $\mathrm{miR} 200 \mathrm{a} / \mathrm{miR} 200 \mathrm{~b}$ levels. However, it is not clear whether an increase in MIR200A/MIR200B expression precedes or succeeds the decline in ZEB2 levels. It has been postulated that there exists a double-negative feedback loop between ZEB and miR200s, which regulates the stability and interchangeability of the EMT phenotype (Gregory et al. 2008, Brabletz \& Brabletz 2010). It is likely that the AR-induced decrease in ZEB2 expression leads to an increase in miR200a/miR200b levels. This presumption is supported by in silico studies, which revealed the presence of ZEB2-binding sites in the regulatory regions of the MIR200A and MIR200B genes (Table 1).

This study provides conclusive evidence for the AR-mediated regulation of ZEB2 expression in PCa cells.
However, this regulation appears to be a contextdependent event (Fig. 11). AR binds to more than 200 proteins that either repress or activate the transcriptional activity of $A R$. These co-repressors or co-activators may compete for a common, or at least partially overlapping, binding site on AR (Nagy et al. 1999). Different levels or the differential recruitment of binding proteins may modulate the ability of AR to act as a repressor in one context and as an activator in another context (van de Wijngaart et al. 2012). In addition, AR binding to chromatin is known to be dependent on certain co-regulatory proteins, such as forkhead protein FOXA1. A modulation in the levels of these co-regulatory proteins is also known to alter the $A R$ cistromes (Sahu et al. 2011). Divergent observations with regard to ZEB2 expression, as observed in this study, could also result from distinct $A R$ transcriptional programs in androgen-dependent and -independent cell lines.

This study supports the inferences drawn by Zhu \& Kyprianou (2010), which suggest that AR maintenance is necessary for EMT regulation. Long-term androgen deprivation downregulates AR expression and induces EMT, which often lead to recurrent prostate tumor growth (Liu et al. 2012). Clinical evidence also suggests that intermittent, rather than continuous, androgen deprivation therapy is more beneficial to patients with locally advanced, metastatic prostate tumors (Boccon-Gibod et al. 2007, Suzuki et al. 2008). Our study also hints that

Published by Bioscientifica Ltd 
the loss of AR expression favors EMT in AI PCa cells. Thus, the regulation of the expression of $\mathrm{AR}$ as well as its co-regulators and downstream effectors may have remarkable implications for metastasis in PCa cells.

\section{Supplementary data}

This is linked to the online version of the paper at http://dx.doi.org/10.1530/ ERC-13-0514.

\section{Declaration of interest}

The authors declare that there is no conflict of interest that could be perceived as prejudicing the impartiality of the research reported.

\section{Funding}

This work was supported by the Indian Council of Medical Research and the Department of Atomic Energy (BRNS), Government of India.

\section{Acknowledgements}

We sincerely thank Prof. Donald Tindall (Mayo Clinic, MN, USA) for providing the human $A R$ CDNA clone and Prof. Danny Huylebroeck (University of Leuven, Belgium) for the human ZEB2 cDNA clone. We thank Dr Nafisa Balasinor, Reshama Gaonkar, and Shobha Potdar for their help in confocal microscopy, Mr P Salunke for his help in microtomy, Dr D Bhartiya for providing vimentin antibodies and Ms Farha Naaz (IIT, Mumbai) for assistance in invasion assays. Ms S Jacob thanks the DAE and ICMR for providing junior and senior research fellowships respectively.

\section{References}

Acloque H, Adams MS, Fishwick K, Bronner-Fraser M \& Nieto MA 2009 Epithelial-mesenchymal transitions: the importance of changing cell state in development and disease. Journal of Clinical Investigation 119 1438-1449. (doi:10.1172/JCI38019)

Alimirah F, Chen J, Basrawala Z, Xin H \& Choubey D 2006 DU-145 and PC-3 human prostate cancer cell lines express androgen receptor: implications for the androgen receptor functions and regulation. FEBS Letters 580 2294-2300. (doi:10.1016/j.febslet.2006.03.041)

Anose BM \& Sanders MM 2011 Androgen receptor regulates transcription of the ZEB1 transcription factor. International Journal of Endocrinology 2011 903918. (doi:10.1155/2011/903918)

Balk SP 2002 Androgen receptor as a target in androgen-independent prostate cancer. Urology 60 132-138 (discussion 138-139). (doi:10. 1016/S0090-4295(02)01593-5)

Boccon-Gibod L, Hammerer P, Madersbacher S, Mottet N, Prayer-Galetti T \& Tunn U 2007 The role of intermittent androgen deprivation in prostate cancer. BJU International 100 738-743. (doi:10.1111/j.1464410X.2007.07053.x)

Brabletz S \& Brabletz T 2010 The ZEB/miR-200 feedback loop - a motor of cellular plasticity in development and cancer? EMBO Reports 11 670-677. (doi:10.1038/embor.2010.117)

Byles V, Zhu L, Lovaas JD, Chmilewski LK, Wang J, Faller DV \& Dai Y 2012 SIRT1 induces EMT by cooperating with EMT transcription factors and enhances prostate cancer cell migration and metastasis. Oncogene $\mathbf{3 1}$ 4619-4629. (doi:10.1038/onc.2011.612)

Emadi Baygi M, Soheili ZS, Essmann F, Deezagi A, Engers R, Goering W \& Schulz WA 2010 Slug/SNAI2 regulates cell proliferation and invasiveness of metastatic prostate cancer cell lines. Tumour Biology $\mathbf{3 1}$ 297-307. (doi:10.1007/s13277-010-0037-5)

Feldman BJ \& Feldman D 2001 The development of androgen-independent prostate cancer. Nature Reviews. Cancer 1 34-45. (doi:10.1038/ 35094009)

Gregory PA, Bert AG, Paterson EL, Barry SC, Tsykin A, Farshid G, Vadas MA, Khew-Goodall Y \& Goodall GJ 2008 The miR-200 family and miR-205 regulate epithelial to mesenchymal transition by targeting ZEB1 and SIP1. Nature Cell Biology 10 593-601. (doi:10.1038/ncb1722)

Gregory PA, Bracken CP, Smith E, Bert AG, Wright JA, Roslan S, Morris M, Wyatt L, Farshid G, Lim YY et al. 2011 An autocrine TGF- $\beta$ /ZEB/ miR-200 signaling network regulates establishment and maintenance of epithelial-mesenchymal transition. Molecular Biology of the Cell 22 1686-1698. (doi:10.1091/mbc.E11-02-0103)

Izumi K, Fang L, Mizokami A, Namiki M, Li L, Lin WJ \& Chang C 2013 Targeting the androgen receptor with siRNA promotes promotes prostate cancer macrophage recruitment via CCL2/CCR2 induced STAT3 activation. EMBO Molecular Medicine 5 1383-1401. (doi:10.1002/ emmm.201202367)

Katoh M \& Katoh M 2009 Integrative genomic analyses of ZEB2: transcriptional regulation of ZEB2 based on SMADs, ETS1, HIF1 •, POU/OCT, and NF-кB. International Journal of Oncology 34 1737-1742. (doi:10.3892/ijo_00000304)

Klymkowsky MW \& Savagner P 2009 Epithelial-mesenchymal transition: a cancer researcher's conceptual friend and foe. American Journal of Pathology 174 1588-1593. (doi:10.2353/ajpath.2009.080545)

Kong D, Li Y, Wang Z, Banerjee S, Ahmad A, Kim HR \& Sarkar FH 2009 miR-200 regulates PDGF-D-mediated epithelial-mesenchymal transition, adhesion, and invasion of prostate cancer cells. Stem Cells $\mathbf{2 7}$ 1712-1721. (doi:10.1002/stem.101)

Leshem O, Madar S, Kogan-Sakin I, Kamer I, Goldstein I, Brosh R, Cohen Y, Jacob-Hirsch J, Ehrlich M, Ben-Sasson S et al. 2011 TMPRSS2/ERG promotes epithelial to mesenchymal transition through the ZEB1/ZEB2 axis in a prostate cancer model. PLoS ONE 6 e21650. (doi:10.1371/ journal.pone.0021650)

Liu T, Wu LY, Fulton MD, Johnson JM \& Berkman CE 2012 Prolonged androgen deprivation leads to downregulation of androgen receptor and prostate-specific membrane antigen in prostate cancer cells. International Journal of Oncology 41 2087-2092.

Miyamoto H, Messing EM \& Chang C 2004 Androgen deprivation therapy for prostate cancer: current status and future prospects. Prostate $\mathbf{6 1}$ 332-353. (doi:10.1002/pros.20115)

Mohler JL 2008 Castration-recurrent prostate cancer is not androgenindependent. Advances in Experimental Medicine and Biology $\mathbf{6 1 7}$ 223-234.

Nagy L, Kao HY, Love JD, Li C, Banayo E, Gooch JT, Krishna V, Chatterjee K, Evans RM \& Schwabe JW 1999 Mechanism of corepressor binding and release from nuclear hormone receptors. Genes and Development $\mathbf{1 3}$ 3209-3216. (doi:10.1101/gad.13.24.3209)

Nieto MI, Finn S, Loda M \& Hahn WC 2007 Prostate cancer: Re-focusing on androgen receptor signaling. International Journal of Biochemistry and Cell Biology 39 1562-1568.

Postigo AA \& Dean DC 2000 Differential expression and function of members of the zfh-1 family of zinc finger/homeodomain repressors. PNAS 97 6391-6396. (doi:10.1073/pnas.97.12.6391)

Ru P, Steele R, Newhall P, Phillips NJ, Toth K \& Ray RB 2012 miRNA-29b suppresses prostate cancer metastasis by regulating epithelialmesenchymal transition signaling. Molecular Cancer Therapeutics 11 1166-1173. (doi:10.1158/1535-7163.MCT-12-0100)

Sahu B, Laakso M, Ovaska K, Mirtti T, Lundin J, Rannikko A, Sankila A, Turunen JP, Lundin M, Konsti J et al. 2011 Dual role of FoxA1 in androgen receptor binding to chromatin, androgen signalling and prostate cancer. EMBO Journal 30 3962-3976. (doi:10.1038/emboj.2011.328)

Shiota M, Bishop JL, Nip KM, Zardan A, Takeuchi A, Cordonnier T, Beraldi E, Bazov J, Fazli L, Chi K et al. 2013 Hsp27 regulates epithelial mesenchymal transition, metastasis, and circulating tumor cells in 
prostate cancer. Cancer Research 73 109-119. (doi:10.1158/0008-5472. CAN-12-3979)

Sun Y, Wang BE, Leong KG, Yue P, Li L, Jhunjhunwala S, Chen D, Seo K, Modrusan Z, Gao WQ et al. 2012 Androgen deprivation causes epithelial-mesenchymal transition in the prostate: implications for androgen-deprivation therapy. Cancer Research 72 527-536. (doi:10. 1158/0008-5472.CAN-11-3004)

Suzuki H, Kamiya N, Imamoto T, Kawamura K, Yano M, Takano M, Utsumi T, Naya Y \& Ichikawa T 2008 Current topics and perspectives relating to hormone therapy for prostate cancer. International Journal of Clinical Oncology 13 401-410. (doi:10.1007/ s10147-008-0830-y)

Thiery JP \& Sleeman JP 2006 Complex networks orchestrate epithelialmesenchymal transitions. Nature Reviews. Molecular Cell Biology $\mathbf{7}$ 131-142. (doi:10.1038/nrm1835)
Vandewalle C, Comijn J, De Craene B, Vermassen P, Bruyneel E, Andersen H, Tulchinsky E, Van Roy F \& Berx G 2005 SIP1/ZEB2 induces EMT by repressing genes of different epithelial cell-cell junctions. Nucleic Acids Research 33 6566-6578. (doi:10.1093/nar/gki965)

van de Wijngaart DJ, Dubbink HJ, van Royen ME, Trapman J \& Jenster G 2012 Androgen receptor coregulators: recruitment via the coactivator binding groove. Molecular and Cellular Endocrinology 352 57-69. (doi:10. 1016/j.mce.2011.08.007)

Xie D, Gore C, Liu J, Pong RC, Mason R, Hao G, Long M, Kabbani W, Yu L, Zhang $\mathrm{H}$ et al. 2010 Role of DAB2IP in modulating epithelialto-mesenchymal transition and prostate cancer metastasis. PNAS $\mathbf{1 0 7}$ 2485-2490. (doi:10.1073/pnas.0908133107)

Zhu ML \& Kyprianou N 2010 Role of androgens and the androgen receptor in epithelial-mesenchymal transition and invasion of prostate cancer cells. FASEB Journal 24 769-777. (doi:10.1096/fj.09-136994)

Received in final form 24 March 2014

Accepted 9 April 2014
Published by Bioscientifica Ltd. 